\title{
PENGARUH PEMBERIAN PUPUK KANDANG AYAM TERHADAP PERTUMBUHAN DAN HASIL TANAMAN SAWI HIJAU (Brassica juncea L.)
}

\author{
Marlinda Bhoki ${ }^{1}$, Julianus Jeksen ${ }^{2}$, Henderikus Darwin Beja ${ }^{3} *$ \\ ${ }^{1,2,3}$ Universitas Nusa Nipa Maumere \\ darwinbeja@ymail.com
}

\begin{abstract}
Abstrak
Tujuan penelitian ini adalah untuk mengetahui pengaruh pemberian pupuk kandang ayam terhadap pertumbuhan dan hasil tanaman sawi hijau (Brassica juncea L.) dan mengetahui dosis optimum pupuk kandang ayam yang dapat memberikan pertumbuhan dan hasil tanaman sawi hijau (B. juncea L.) yang optimal. Metode yang digunakan dalam penelitian ini adalah Rancangan Acak Kelompok (RAK) dengan empat ulangan dan enam perlakuan yaitu, K0 : 0 ton / ha atau tanpa pupuk, K1: 20 ton/ha, K2: 30 ton/ha, K3: 40 ton/ha, K4: 50 ton/ha, K5: 60 ton/ha. Berdasarkan hasil analisis sidik ragam menggunakan rancangan acak kelompok (RAK) hasil penelitian diperoleh bahwa pemberian pupuk kandang ayam tidak berpengaruh nyata terhadap tinggi tanaman, jumlah daun dan berpengaruh sangat nyata terhadap berat segar $\tan ^{-1}$ dan berat segar ha ${ }^{-1}$. Dosis optimum pupuk kandang ayam 60 ton ha ${ }^{-1}$ merupakan perlakuan terbaik untuk pertumbuhan dan hasil tanaman sawi hijau (B. juncea L.) yang optimal dengan produksi rata-rata berat segar ha-1 mencapai 17,26 ton $\mathrm{ha}^{-1}$.
\end{abstract}

Kata kunci: pupuk kandang ayam, tanaman sawi, pertumbuhan, hasil.

\section{Abstract}

The purpose of this study is to know the effect of chicken manure on the growth and yield of green mustard plants (B. juncea L.) and to know the optimum dose of chicken manure that can provide optimal growth and yield of green mustard plants (B. juncea L.). The method used in this study is RandomIzed Group Design (RAK) with four replays and six treatments namely, KO: 0 ton / ha or without fertilizer, K1: 20 tons / ha, K2: 30 tons / ha, K3: 40 tons / ha, K4: 50 tons / ha, K5: 60 tons / ha. Based on variance analysis using a randomized design of the group $(R A K)$ the results of the study obtained that the treatment of chicken manure has no real effect on the height of the plant, the number of leaves and has a very noticeable effect on the fresh weight of $\tan ^{-1}$ and the fresh weight of $\mathrm{ha}^{-1}$. The optimum dose of chicken manure 60 tons $h^{-1}$ is the best treatment for the growth and yield of green mustard plants (B. juncea L.) optimal with the average production of fresh weight ha $a^{-1}$ reaches 17.26 tons $h a^{-1}$.

Keyword: chicken manure, mustard plants, growth, yield.

\section{Pendahuluan}

Tanaman sawi hijau (B. juncea L.) berasal dari China dan Asia Timur dan telah dibudidayakan sejak 2500 tahun yang lalu. Tanaman sawi hijau merupakan salah satu tanaman hortikultura yang sangat digemari masyarakat. Tanaman sawi hijau juga mengandung nutrisi yang dibutuhkan oleh tubuh manusia yaitu protein, lemak, karbohidrat, kalsium, fosfor, vitamin A, vitamin $\mathrm{B}$, dan vitamin $\mathrm{C}$ (Cahyono, 2003).

Produksi tanaman sawi pakcoy mengalami penurunan yaitu dari 635,728 ton/tahun pada 2013 menjadi 602,468 ton/tahun pada tahun (BPS, 2015) dan Direktorat Jenderal Hortikultura, 2015). Penyebab penurunan produksi adalah petani melakukan kegiatan budidaya tanaman pakcoy yang belum tepat yaitu pemupukan.

Peningkatan produksi yang optimal pada tanaman sawi, perlu diperhatikan dalam sistem budidaya dan pemupukan. Pemupukan adalah pemberian atau penambahan unsur hara untuk melengkapi unsur hara tanah, bertujuan untuk meningkatkan pertumbuhan tanaman. Pupuk organik terdiri dari dua jenis, yaitu pupuk organik cair dan pupuk organik padat. Salah satu contoh pupuk organik padat yaitu kotoran ayam. Pupuk organik merupakan pupuk yang mengandung senyawa organik. Pupuk organik berasal dari alam dan dapat diolah secara alami atau melalui rekayasa.Contoh dari pupuk organik adalah kompos dan pupuk kandang. Pupuk kandang berasal dari kotoran ayam dapat katakansebagai pupuk organik, pupuk dari kotoran ayam memiliki reaksi yang lebih cepat dibandingkan dengan kotoran hewan lainnya, sehingga cocok dengan karakter tanaman yang memiliki siklus tanaman yang berumur pendek.

Kotoran ayam mengandung nitrogen yang tinggi. Salah satu cara untuk meningkatkan produksi tanaman sawi yaitu dengan pemberian pupuk sesuai dengan kebutuhan tanaman. Ketersediaan unsur hara mampu berpengaruh pada pertumbuhan dan hasil, tanaman membutuhkan nutrisi cukup di dalam tanah. Jika tanaman kekurangan unsur hara akan 
menghambat pertumbuhan tanaman. Pemupukan merupakan kunci utama kesuburan tanah karena mengandung unsur hara untuk menggantikan unsur hara yang sudah diserap tanaman (Lingga dan Marsono, 2005). Cindera et al. (2013), pemberian pupuk kandang ayam sebanyak 20 ton $/ \mathrm{ha}^{-1}$ dengan hasil $215 \mathrm{~g}^{-1}$ ton paling berpengaruh terhadap pertumbuhan dan hasil tanaman sawi.

\section{Bahan dan Metode}

Penelitian ini susun berdasarkan berdasarkan Rancangan Acak Kelompok (RAK) dengan enam (6) perlakuan dosis pupuk kandang ayam yaitu :

K0 : Tanpa pupuk ( kontrol )

$\mathrm{K} 1$ : Pupuk kandang ayam 20 ton $\mathrm{ha}^{-1}$ atau 4 $\mathrm{kg} /$ petak

K2 : Pupuk kandang ayam 30 ton ha $^{-1}$ atau 6 $\mathrm{kg} /$ petak

K3 : Pupuk kandang ayam 40 ton $\mathrm{ha}^{-1}$ atau 8 $\mathrm{kg} /$ petak

K4 : Pupuk kandang ayam 50 ton $\mathrm{ha}^{-1}$ atau 10 $\mathrm{kg} /$ petak

K5 : Pupuk kandang ayam 60 ton $\mathrm{ha}^{-1}$ atau 12 $\mathrm{kg} /$ petak

Setiap perlakuan diulang sebanyak empat (4) kali sehingga terdapat 24 unit percobaan.

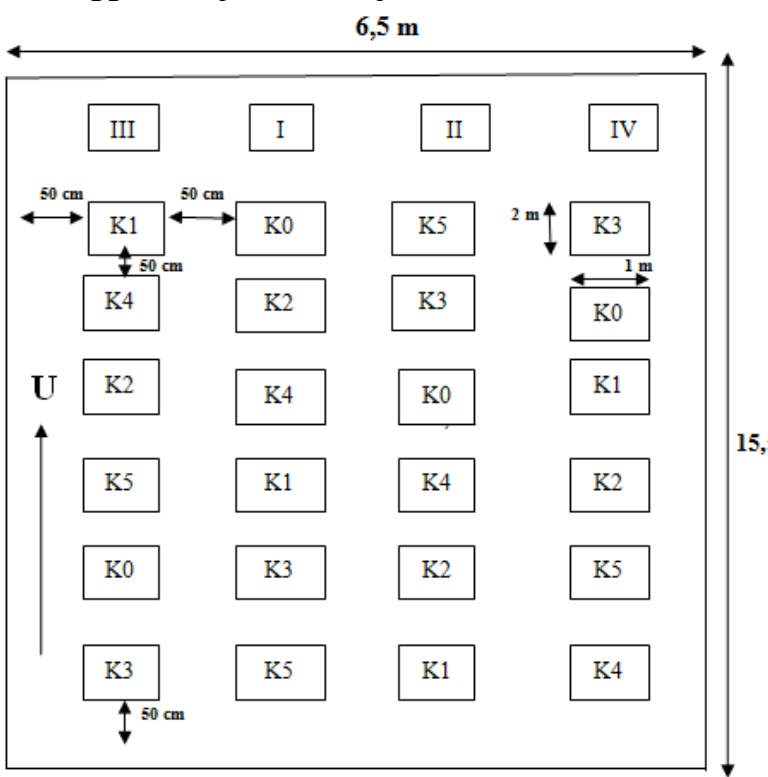

Gambar 1. Denah Plot Percobaan di Lapangan

Keterangan:

I, II, III, IV: Blok

K0-K5: Perlakuan

K0 : Tanpa pupuk ( kontrol )

K1: Pupuk kandang ayam 20 ton $\mathrm{ha}^{-1}$

K2: Pupuk kandang ayam 30 ton ha ${ }^{-1}$

K3: Pupuk kandang ayam 40 ton ha ${ }^{-1}$

K4: Pupuk kandang ayam 50 ton $\mathrm{ha}^{-1}$

K5: Pupuk kandang ayam 60 ton $\mathrm{ha}^{-1}$

Jarak antara ulangan $\quad: 50 \mathrm{~cm}$ $\begin{array}{ll}\text { Jarak antara perlakuan } & : 50 \mathrm{~cm} \\ \text { Luas lahan } & : 15,5 \mathrm{~m} \times 6,5 \mathrm{~m}\end{array}$

\section{Hasil dan Pembahasan}

Berdasarkan hasil analisis statistik menunjukkan bahwa pemberian pupuk kandang ayam terhadap pertumbuhan dan hasil tanaman sawi (B. juncea L.) tidak memberikan pengaruh nyata terhadap tinggi tanaman, jumlah daun, tetapi berpengaruh sangat nyata terhadap berat segar $\tan ^{-1}$ ,berat segar ha ${ }^{-1}$

Tabel 1. Signifikasi Pengaruh Pemberian Pupuk Pupuk Kandang Ayam Terhadap Pertumbuhan dan Hasil Tanaman Sawi Hijau (Brassica juncea L.)

\begin{tabular}{cll}
\hline No & \multicolumn{1}{c}{ Variabel } & Signifikasi \\
\hline 1 & Tinggi tanaman 14hst & TN \\
\hline 2 & Tinggi tanaman 21 hst & TN \\
\hline 3 & Jumlah daun 14 hst & TN \\
\hline 4 & Jumlah daun 21 hst & TN \\
\hline 5 & Berat segar sawi tan $^{-1}$ & $* *$ \\
\hline 6 & Berat segar sawi ha $^{-1}$ & $* *$ \\
\hline
\end{tabular}

\section{Keterangan :}

TN : Tidak Nyata

** : Sangat Nyata

Hasil analisis sidik ragam menunjukkan bahwa pemberian pupuk kandang ayam terhadap pertumbuhan dan hasil tanaman sawi hijau (Brassica juncea L.) tidak memberikan pengaruh nyata pada variabel pertumbuhan. 
Tabel 2. Pengaruh Pupuk Kandang Ayam

\begin{tabular}{|c|c|c|c|}
\hline \multirow{2}{*}{ Variabel } & \multirow{2}{*}{ Perlakuan } & \multicolumn{2}{|c|}{$\begin{array}{c}\text { Umur pengamatan } \\
\text { (hst) }\end{array}$} \\
\hline & & 14 & 21 \\
\hline \multirow{6}{*}{$(\mathrm{cm})$} & K0 & $8.96 \mathrm{a}$ & $21.42 \mathrm{a}$ \\
\hline & K1 & $11.00 \mathrm{a}$ & $22.63 \mathrm{a}$ \\
\hline & $\mathrm{K} 2$ & $11.63 \mathrm{a}$ & $21.46 \mathrm{a}$ \\
\hline & K3 & $11.50 \mathrm{a}$ & $22.13 \mathrm{a}$ \\
\hline & K4 & $10.21 \mathrm{a}$ & $21.38 \mathrm{a}$ \\
\hline & K5 & $11.63 \mathrm{a}$ & $22.96 \mathrm{a}$ \\
\hline \multirow{6}{*}{ (helai) } & K0 & $4.92 \mathrm{a}$ & $8.13 \mathrm{a}$ \\
\hline & K1 & $4.88 \mathrm{a}$ & $7.08 \mathrm{a}$ \\
\hline & $\mathrm{K} 2$ & $4.92 \mathrm{a}$ & $7.17 \mathrm{a}$ \\
\hline & K3 & $5.25 \mathrm{a}$ & $7.25 \mathrm{a}$ \\
\hline & K4 & $5.25 \mathrm{a}$ & $7.67 \mathrm{a}$ \\
\hline & K5 & $5.50 \mathrm{a}$ & $7.63 \mathrm{a}$ \\
\hline
\end{tabular}

Berdasarkan hasil analisis ragam, tanaman yang diberi pupuk dan tanaman yang tidak diberi pupuk memberikan hasil yang sama, dan tanaman yang diberi perlakuan harus memberikan pertumbuhan yang baik . Artinya perlakuan K0 dengan atau tanpa pupuk memiliki hasil yang sama dengan perlakuan K1-K5, hal ini disebabkan lambatnya pelepasan unsur hara pada kotoran ayam, karena unsur hara yang terdapat pada kotoran sulit terurai. Widowati (2004) menunjukkan bahwa lamanya proses pembusukan pada pupuk dipengaruhi oleh tekstur dari pupuk itu sendiri. Teksturnya berbentuk seperti partikel padat yang sulit terurai secara fisik, sehingga kecepatan penguraiannya sangat lambat, dan tanaman tidak dapat menyerap unsur hara sehingga menyebabkan tanaman membutuhkan waktu lama untuk tumbuh. Pernyataan tersebut menunjukkan bahwa Hipotesis 1 ditolak karena tidak berpengaruh terhadap tinggi tanaman dan jumlah daun. Dalam hal ini tanaman dianggap kekurangan unsur hara yang dibutuhkan, dan pembentukan unsur Nitrogen, Phospor dan Kalium tidak mencukupi untuk diserap oleh tanaman sehingga relative sedikit unsur hara yang diserap pada tanaman.

Menurut penelitian Lakit (2001) pertumbuhan tanaman yang baik adalah melalui pemupukan. Pemupukan adalah upaya menambah unsur hara pada tanah yang dapat meningkatkan hasil kesuburan tanah dan hasil tanaman. Pemupukan yang tidak tepat jenis, dosis, waktu, dan cara pemupukan dapat menyebabkan gangguan pada tanaman dan menghambat pertumbuhan tanaman yang baik. Unsur $\mathrm{N}$, P, dan $\mathrm{K}$ merupakan unsur yang diperlukan dalam jumlah yang cukup bagi tumbuhan.

Unsur-unsur yang terkandung dalam kotoran ayam termasuk unsur makroskopis seperti $\mathrm{N}, \mathrm{P}$ dan $\mathrm{K}$. Pentingnya unsur $\mathrm{N}, \mathrm{P}$ dan $\mathrm{K}$ dalam proses pertumbuhan tanaman, unsur $\mathrm{N}$ sangat berguna untuk mendorong pertumbuhan vegetatif tanaman. Pertumbuhan akar, batang dan pembentukan daun hijau (klorofil) sangat penting untuk proses fotosintesis. Unsur P mendorong pertumbuhan akar, pembentukan bunga, dan kematangan buah. Unsur kalium berperan penting dalam penyerapan air dan unsur hara di dalam tanah, serta mendistribusikan produk fotosintesis dari daun ke seluruh jaringan tanaman.

Hasil analisis sidik ragam menunjukkan bahwa pemberian dosis pupuk kandang ayam memberikan pengaruh sangat nyata terhadap jumlah berat segar $\tan ^{-1}$ dan berpengaruh sangat nyata berat segar sawi ha ${ }^{-1}$ (B. juncea $\left.\mathrm{L}\right)$.

Tabel 3. Pengaruh Pupuk Kandang Ayam Terhadap Hasil Tanaman Sawi Hijau (B. juncea L).

\begin{tabular}{cll}
\hline Perlakuan & \multicolumn{2}{c}{$\begin{array}{c}\text { Rata-Rata Variabel } \\
\text { Pengamatan }\end{array}$} \\
\cline { 2 - 3 } & $\begin{array}{l}\text { Berat Segar } \\
\text { Sawi Tan } \\
\text { (gram) }\end{array}$ & $\begin{array}{l}\text { Berat Segar } \\
\text { Sawi Ha } \\
\text { (ton) }\end{array}$ \\
\hline K0 & $76.38 \mathrm{a}$ & $12.22 \mathrm{a}$ \\
\hline K1 & $87.38 \mathrm{~b}$ & $13.88 \mathrm{~b}$ \\
\hline K2 & $88.46 \mathrm{c}$ & $14.15 \mathrm{c}$ \\
\hline K3 & $104.71 \mathrm{~d}$ & $16.75 \mathrm{~d}$ \\
\hline K4 & $106.04 \mathrm{e}$ & $16.96 \mathrm{e}$ \\
\hline K5 & $107.92 \mathrm{f}$ & $17.26 \mathrm{f}$
\end{tabular}

Keterangan: Angka-angka yang diikuti oleh huruf yang sama pada kolom yang sama menunjukan tidak berbeda nyata pada taraf uji BNT 5\%

Hasil analisis ragam menunjukkan bahwa pemberian pupuk kandang berpengaruh nyata terhadap bobot segar tanaman sawi dan $\mathrm{ha}^{-1}$ tanaman sawi segar, serta pemberian pupuk kandang ayam memberikan hasil yang paling tinggi. 60 ton ha-1 (K5), hasil rata-rata 17,26 ton ha $^{-1}$, hasil terendah yang bisa diperoleh dengan pemberian 0 ton $\mathrm{ha}^{-1}$ kotoran ayam atau kotoran ayam tanpa pupuk (K0), rata-rata 12,22 ton $\mathrm{ha}^{-1}$ dibandingkan dengan kedua metode perlakuan tersebut, hasil panen meningkat sebesar 29,20\% atau selisih 5,04 ton Pernyataan ini 
menunjukkan bahwa hipotesis 1 diterima karena kotoran ayam berpengaruh terhadap bobot segar tan sayur sawi $\tan ^{-1}$ dan berat segar sayuran sawi ha ${ }^{-1}$. Tanaman sawi diduga telah mengalami pelepasan unsur hara. Kotoran ayam mengandung nutrisi seperti nitrogen, fosfor dan kalium.

Fungsi unsur hara nitrogen adalah berperan sebagai komponen protein, merangsang pertumbuhan daun yang lebih luas dengan kandungan klorofil yang lebih tinggi, serta menghasilkan karbohidrat atau asimilasi yang baik untuk pertumbuhan tanaman, yang pada akhirnya dapat memberikan hasil terbaik dan menjadikannya Sangat cocok untuk budidaya sayuran. Fungsi fosfor, seperti halnya sawi, berperan penting dalam proses penyerapan air dan unsur hara dari tanah serta mendistribusikan produk fotosintesis dari daun ke seluruh jaringan tanaman. Peran kalium adalah membentuk bunga, buah, dan biji, serta merangsang pertumbuhan akar sehingga meregang dan tumbuh kuat sehingga tahan terhadap kekeringan. Menurut (Widowati, 2004), akar lebih mudah menyerap hara di dalam tanah. Unsur hara yang diserap akan digunakan pada tanaman dan menambah bobot segar tanaman, jika unsur hara yang dibutuhkan diperoleh dalam bentuk yang sesuai untuk penyerapan akar dan mencukupi, tanaman akan tumbuh dan berkembang. Ketika jenis pupuk, dosis, waktu, dan cara aplikasi yang digunakan benar, maka respon tanaman terhadap pemupukan akan meningkat.

Muhsin (2003) mengemukakan bahwa pupuk kandang ayam memiliki potensi bagus karena selain memperbaiki sifat fisik, kimia dan biologi tanah, kotoran ayam juga memiliki kandungan Nitrogen, Phospor dan Kalium yang tinggi dibandingkan pupuk kandang lainnya. Hasil dari ketiga proses tersebut adalah akumulasi asimilasi melalui fotosintesis, asimilasi berkurang karena respirasi, dan penumpukan cadangan makanan memiliki penyerapan $\mathrm{CO} 2$ (fotosintesis) dan $\mathrm{CO} 2$ (respirasi) yang seimbang, jika respirasi Lebih dari fotosintesis, maka tanaman akan mengalami kekurangan berat badan (Perlman, 2007).

\section{Kesimpulan}

1. Pemberian pupuk kandang ayam tidak memberikan berpengaruh nyata terhadap tinggi tanaman sawi dan jumlah daun sawi umur 14 dan 21 HST, namun pemberian pupuk kandang ayam menunjukkan pengaruh yang sangat nyata terhadap bobot sayuran sawi dan bobot tanaman sawi ta ${ }^{-1}$ dan berat sawi ha ${ }^{-1}$.

2. Dosis optimal 60 ton $\mathrm{ha}^{-1}$ pupuk kandang ayam untuk hasil terbaik dan. dengan produksi ratarata 17,26 ton ha- ${ }^{1}$

\section{Ucapan terimakasih}

Terimakasih kepada pihak yang telah memberikan sumbangsihnya terhadap penyelesaian penelitian ini, para dosen maupun teman-teman seangkatan.

\section{Daftar Pustaka}

Anonimous. 2009. Pedoman bertanam sawi hijau. Iramawidya. Bandung.

Anonimus. 2010. Peranan Bahan Organik Terhadap Kesuburan Tanah dan Tanaman. http://blog.unila.ac.id/wasetawan/files/2010/ 10/peranan-bahan-organik-terhadap kesuburan-tanah-tanaman.pdf. Disitir tanggal 06 Agustus 2010.

Barbarick K. A. 2006. Nitrogen Sources and Transformations. Colorado State University. U.S. Department of Agriculture and Colorado counties cooperating.

BPS https://sikkakab.bps.go.id/publication/2016/ 01/27/43a220421caaf84163575085/sikkadalam-angka-2015.html

Cahyono, B. 2003. Teknik dan Strategi Budidaya Sawi Hijau (Pet-Sai). Yayasan Pustaka Nusantara.Yogyakarta. Hal 117.

Cindra, D. S., Pomalingo, N., \& Nurmi. 2013.Pengaruh Pemberian Pupuk Organik Kandang Ayam Terhadap Pertumbuhan Dan Produksi Tanaman Sawi. Universitas Gorontalo. Gorontalo.

Direktorat Jenderal Hortikultura. 2013-2015. Statistik Produksi Hortikultura. Di akses tanggal 16 November 2020.

Gomes dan Gomes. 1995. Prosedur statistik untuk Penelitian Pertanian. Edisi Kedua. (Diterjemahkan oleh Endang Samsuddin dan Yustika S. Bahar sjha). Jakarta. Universitas Indonesia Press

Haryanto 2006. Teknik budidaya tanaman sawi . Jakarta. Penebar Swadaya.

Jusuf, L. 2006. Potensi Daun Krisan Terfermentasi Sebagai Pupuk Organik Cair. Gowa: Balai Penyuluhan Pertanian (Stpp). Jurnal Penelitian Pertanian, Juni 2006, Volume 2, Nomor 1 Issn 1858-4330.

Lakitan. B. 2004. Dasar-dasar Fisiologi Tumbuhan. Raja Grafindo Perseda. Jakarta.

Lakit. 2001. Bahan Organik Terhadap Kesuburan Tanah dan Tanaman.

Lingga.P. Dan Marsono. 2005,Petunjuk Penggunaan Pupuk. Penebar Swadaya. Jakarta. $50 \mathrm{hlm}$.

Margiyanto, E. 2007. Budidaya Tanaman Sawi. Yayasan Pustaka Nusantara. Yogyakarta. Novizan. 2005.

Muhsin, (2003). Aplikasi Pupuk Kandang Ayam Untuk Pertumbuhan Dan Produksi Ketimun (Cucumi sativus L.). prosa. Sekolah Tinggi 
Pertanian Universitas Taman Siswa (Universitas Taman Siswa). Padang.

Nasrul, Nastain. 2011 Unsur - unsur tanaman dan fungsinya yang dibutuhkan tanaman.

Iman. (2007). Aplikasi Pupuk Kandang Ayam Untuk Pertumbuhan Dan Produksi

Rukmana. 1994. Bertanam Petsay dan sawi. Kanisius. Yogyakarta.

Sanusi, A, Setyono2, Sjarif A. Adimihardja. (2015). Jumlah Pupuk Kandang Dan Pupuk Nitrigen, Phospor Dan Kalium Yang Berbeda Untuk Pertumbuhan Dan Hasil Produksi Tanaman Sawi. Jurnal Agronides ISSN 2407-Nilai Median X 2 Juni 2018, Pengaruh Jenis Pupuk Terhadap Pertumbuhan dan Produksi Sawi 119111 Volume 1, Edisi 1, April 2015.

Saparinto, C, Panduan Praktis Menanam 14 Sayuran Konsumsi Populer di Pekarangan. Yogyakarta: Penerbit ANDI.
Sarwono, H. 2007. Ilmu Tanah. Akademik Presindo. Jakarta. 288 hal.

Setyaningrum, H. D dan C. Saparinto. 2011. Sayuran dipanen secara teratur di lahan sempit. Komunikator swalayan, Jakarta

Sunarjono, H. 2004. Bertanam Sawi dan Selada. Penebar Swadaya. Jakarta. Hal 132.

Supriati, Y dan E, Herlina. 2010. Bertanam Sayuran Organik Dalam Pot. Penebar Swadaya. Jakarta. Hal 192. Susanti, T. 2011.

Sutedjo, M. M. 2001. Pupuk dan Cara Pemupukan. Penerbit Rineka Cipta. Jakarta.

Widowati. (2004). Pengaruh Kompos Pupuk Organik Yang Kaya Mineral Dan Pupuk Hayati Terhadap Sifat Tanah, Penyerapan Hara Dan Produksi Sayuran Organik. Laporan Proyek Penelitian Tentang Rencana Pengembangan Usaha Agribisnis. Lembaga Penelitian Tanah. 